\title{
The COVID-19 Pandemic: Challenges Faced and Lessons Learned Regarding Distance Learning in Lebanese Higher Education Institutions
}

\author{
Maha Mouchantaf \\ Notre Dame University, Louaize, Beirut, Lebanon
}

\begin{abstract}
In the past few months, due to the Covid-19 (Coronavirus) outbreak, most educational establishments in Lebanon, including schools and higher education institutions, made the transition to distance learning. This research sought to explore the impact of the Covid-19 pandemic and the challenges that it currently poses to higher education. More specifically, it aimed to evaluate the views of language teachers with regards to online teaching to better understand both its advantages and disadvantages in comparison to faceto-face education. The study also offered insight on the educator's feedback and their presented solutions that will lead to a better experience with online learning. A quantitative cross-sectional online survey was implemented for the purpose of this study.
\end{abstract}

Index Terms - online education, language teaching, crisis management, educational technology, staff development, educational platforms

\section{INTRODUCTION}

In the last decade, Internet usage, increased online connectivity and access to new technologies such as smartphones, have paved the way for diverse methods of social interaction, and access to information (Swicord, Chancey \& BriceDavis, 2013). Between 2005 and 2019 the prevalence of social media use among US adults increased from 5\% to over $70 \%$. Nowadays, students use the Internet and other forms of technology for a wide range of purposes (Swicord, Chancey \& Brice-Davis, 2013). A study reported that students who have regular access to the Internet at home become frustrated when they cannot use it when and where they want, including in the classroom. The participants believed that technology could enrich their overall learning experience (Project Tomorrow, 2006). Research has also linked technology to educational achievements in US classrooms. For instance, Bain and Ross found that combining course content with technology significantly increased students' understanding of what was taught as well as their overall achievement (2000).

Over the past few months, due to the Covid-19 (Coronavirus) outbreak, most educational establishments in Lebanon including schools and higher education institutions have made the transition to distance learning. Distance learning, according to Greenberg (1998), is a "planned teaching/learning experience that uses a wide spectrum of technologies to reach learners at a distance and is designed to encourage learner interaction and certification of learning" (p.36). Classes have been undertaken in a variety of different formats including pre-recorded lectures or live sessions. The Ministry of Education and Higher Education has launched National Distance Learning projects to provide e-learning services for schools and universities via a range of online platforms including YouTube, Zoom, and Microsoft Teams. Despite the government's efforts to ease this transition, Lebanon's financial and banking crisis is resulting in clear setbacks (Wazzan, 2020).

\section{ONLINE LEARNING VS FACE TO FACE}

Digital media has enriched the teaching and learning experience. Worldwide, the use of e-learning has increased with many governments providing promotional programs and financial support (e.g. United States, Austria and Lebanon). The advancement of e-learning has also been influenced by technological developments and learning management systems including Blackboard- and Moodle-based applications (Paechter \& Maier, 2010). Aiming to better understand students' experiences with regard to e-learning, a study was conducted involving 2,196 Austrian university students which explored their preferred online and face-to-face learning components (Paechter \& Maier, 2010). Students mainly appreciated e-learning for its clear and coherent structure, its flexibility and its variety of modes of communication including the fact that the instructor was readily accessible. For face-to-face sessions, students preferred aspects such as the ability to establish positive social relations with their peers and the instructor, the cooperative learning system, and the application of one's knowledge. Both online and face-to-face learning entailed advantages and disadvantages according to the students. Rates of online enrollments have been growing worldwide, specifically in higher education, suggesting that online learning is becoming a more viable teaching and learning strategy in the higher educational system (Flowers, White, Raynor \& Bhattacharya, 2012). In a study surveying university administrators that sought to 
learn about their views regarding the future of online education, most participants believed that it could actually deliver economic, learning and teaching advantages (Allan \& Seaman, 2010). In addition, it has been suggested that online learning can offer remote access to 24-hour classroom information (Ally, 2011). Despite its numerous benefits, online learning alone does not fully address students' needs in understanding and acquiring the course material. The development of cognitive and social skills through mutual feedback and debates allow for better cognitive presence (Fletcher \& Major, 2006).

\section{THE CASE OF LEBANON}

Lebanon is presently confronted with a debt, currency and banking crisis that has impacted on its educational sector. Unlike many countries where public schools are the default, trusted, option, much of Lebanon trusts in its private schools, which educate two thirds of its students (Nakhoul \& Perry, 2019). The education system in Lebanon was strained and was facing challenges before the Covid-19 outbreak. Multiple schools were shutting down and families were struggling to afford private schooling while public schools were becoming overcrowded with Lebanese students and Syrian refugees having access to only limited resources to provide for their needs (Abu Habib, 2020). As already mentioned above, the Ministry of Education and Higher Education launched a National Distance Learning Project to provide e-learning support for public schools during the Covid-19 outbreak (Wazzan, 2020). The Ministry also invited educators to volunteer in recording lessons and made communication platforms such as Microsoft Teams freely available to students. Teachers are using diverse methods to transmit course information such as sending content via WhatsApp, using Zoom to hold classes, sending recommended readings and assignments via email or simply moving content to a proper learning management system in schools that have access to this facility. According to Wazzan, despite governmental efforts to enhance the speed and bandwidth of the country's Internet services, educators and students struggle with connectivity issues during online classes (2020). Educators stated that the process of online learning is in overwhelming, but that positive results are achievable. The time needed for course preparation is longer as compared to normal face-to-face classes and teachers are finding it difficult to complete the curriculum. However, many teachers are helping one another by sharing their experiences in order to improve the process of distance learning.

The purpose of this study is to explore the Covid-19 pandemic and the challenges that it is currently posing on higher education. More specifically, it aims to evaluate the views of teachers with regards to online teaching to better understand its advantages as well as its disadvantages in comparison to face-to-face education. The study also reveals insights drawn from the educators' feedback and presents solutions for an overall better experience regarding online learning.

\section{METHODS}

\section{A. Participants and Procedure}

A quantitative cross-sectional online survey was designed and implemented for the purpose of this study. The Dean and Chairperson of the English Department at Notre Dame University granted ethical approval. They provided the author with a randomly generated list of 300 teachers' emails from five different universities: Lebanese American University, Notre Dame University, Haigazian University, Antonine University, and the American University of Beirut. All data and information was stored securely. Email invitations were sent through the author's private email and linked to an individualized token, allowing each teacher to complete the survey anonymously and only once. Two reminders were sent at a two-week interval. Consent was required prior to participation in the study.

\section{B. Instruments}

In the absence of work directly related to how teachers were adapting to online learning, the authors were inspired by a Cambridge University Press survey on a similar topic and created a 13-item questionnaire. The questionnaire was divided into three sections: the first section required demographic information such as the teacher's age, role in their university and the course being taught; the second section explored the participants' views on online teaching and its impact on students; the third section addressed the future of online teaching and what help the institution's was offering to teachers. Participants were asked to choose answers that best corresponded to their online teaching experience or to provide a rating on a 5-point Likert Scale spanning from (1) to (5) (e.g. "How do you feel about using new online resources? Select a number from 1 to 5 , where 1 = very uncomfortable, and $5=$ very comfortable"). (Appendix).

\section{Data Analysis}

The data was analysed using SPSS version 24.0. Descriptive statistics were generated to better grasp the participants' demographics including frequencies of each variable's characteristic. Pearson's Chi-Square was calculated to investigate any statistically significant associations between engagements in online teaching and the following variables: the help offered by the institution, comfort in using video applications, technical complications, concerns about academic transparency, availability (of the lack) of equipment, training for teachers and student attendance.

Furthermore, a binary logistic regression was conducted to assess whether the additional preparation required on the part of the teacher was associated with a lack of training from the intuitional and to check if students missing online 
sessions or not completing the required work was associated with the lack of help being offered by the institution.

\section{Results}

\section{A. Demographics}

From the 300 teachers and administrators who received the email invitation and reminders, a total of 50 responses were collected. 90\% ( $\mathrm{N}=45)$ of respondents were Instructors, Lecturers or Teachers, and 10\% ( $\mathrm{N}=5)$ were Administrators with teaching duties. There was considerable diversity in the courses being taught, including English, $30 \%(\mathrm{~N}=15)$, Spanish, $20 \%(\mathrm{~N}=10)$, Italian 14\% $(\mathrm{N}=7)$, Communication Arts, $6 \%(\mathrm{~N}=3)$, Languages and Translation, $24 \%(\mathrm{~N}=12)$ and Arabic, 6\% $(\mathrm{N}=3)$. The age group stretched from under 30 to above 50. Table 1 provides an overview of the sample characteristics. When asked how long they have been teaching online, all respondents reported 3 to 10 weeks, $100 \%(\mathrm{~N}=50)$. Additionally, 54\% $(\mathrm{N}=27)$ reported that they teach more than 6 hours per week, 24\% ( $\mathrm{N}=12) 4$ to 6 hours and $22 \%(\mathrm{~N}=11)$ teach 2 to 4 hours per week (Table 1).

TABLE 1.

DEMOGRAPHICS $(\mathrm{N}=50)$

\begin{tabular}{|c|c|c|c|}
\hline & & $N$ & $\%$ \\
\hline \multirow{2}{*}{ ROLE } & INSTRUCTOR & 45 & 90.0 \\
\hline & ADMINISTRATOR & 5 & 10.0 \\
\hline \multirow[b]{2}{*}{ AGE GROUP } & UNDER 30 & 1 & 2.0 \\
\hline & 30 то 40 & 10 & 20.0 \\
\hline \multirow{3}{*}{ FIELD OF STUDY } & ENGLISH & 15 & 30.0 \\
\hline & SPANISH & 10 & 20.0 \\
\hline & COMMUNICATION ARTS & 3 & 6.0 \\
\hline \multirow{2}{*}{ HOURS SPENT TEACHING PER WEEK } & 4 TO 6 HOURS & 12 & 24.0 \\
\hline & MORE THAN 6 HOURS & 27 & 54.0 \\
\hline \multirow{3}{*}{ THOUGHTS ON ONLINE TEACHING } & MORE DIFFICULT THAN I THOUGHT & 9 & 18.0 \\
\hline & AS EXPECTFD & 20 & 580 \\
\hline & VERY SIMPLE AND EASY & 12 & 24.0 \\
\hline
\end{tabular}

\section{B. Transition to Online Teaching}

When asked about the factors that affect online teaching, 60\% ( $\mathrm{N}=30)$ mentioned technical complications (e.g. incorrect or unknown passwords, platforms not working as expected or Internet issues), 50\% ( N= 25) stated concerns about academic transparency and integrity and $30 \%(\mathrm{~N}=15)$ reported a lack of training for teachers and/or institutional support. $64 \%(\mathrm{~N}=32)$ of the sample revealed that students missing online sessions or nor completing the required work affected online teaching, with $46 \%(\mathrm{~N}=23)$ stating that too much preparation is required from the teacher. The lack of equipment (hardware or $\mathrm{Wi}-\mathrm{Fi})$ was also reported to affect sessions $(42 \%, \mathrm{~N}=21)$ as did the students' confusion when introduced to new material $(44 \%, \mathrm{~N}=22)$ (Table 2). Interestingly, only 10\% ( $\mathrm{N}=5)$ reported no major issues with regards to online teaching.

TABLE 2.

FACTORS INFLUENCING ONLINE TEACHING (N=50)

\begin{tabular}{lc}
\multicolumn{2}{c}{ FACTORS INFLUENCING ONLINE TEACHING (N=50) } \\
\hline
\end{tabular}


With regards to the resources that teachers started using when the pandemic began, the majority of the sample (92\%, $\mathrm{N}=46$ ) stated that they used video applications for face-to-face instruction such as Zoom, Skype of Microsoft Teams. $54 \%(\mathrm{~N}=27)$ reported using platforms for posting work such as Google Classroom, Canvas, Blackboard or Class Dojo, $34 \%(\mathrm{~N}=17)$ chose digitised books or eBooks, and 44\% ( $\mathrm{N}=22)$ stated using open Educational Resources (OER).

Results also revealed that $86 \%(\mathrm{~N}=43)$ of participants stated that platforms for posting work such as Google Classroom, Canvas, Blackboard or Class Dojo where available to their institution prior the start of the pandemic as along with digitised books and eBooks $(54 \%, \mathrm{~N}=27)$ and Open Educational Resources $(46 \%, \mathrm{~N}=23)$.

\section{Views on Online Teaching}

In the overall sample, $(\mathrm{N}=50)$, the majority of participants $58 \%(\mathrm{~N}=29)$ stated that the difficulty of online teaching was as expected, $24 \%(\mathrm{~N}=12)$ thought it was very simple and easy and, finally, $18 \%(\mathrm{~N}=9)$ reported that it was more difficult than expected. When asked how comfortable they felt using the new resources $(1=$ very uncomfortable and $5=$ very comfortable), most participants $(46 \%, \mathrm{~N}=23)$ selected $4,30 \%(\mathrm{~N}=15)$ said 5 and $24 \%(\mathrm{~N}=12)$ picked $3.68 \%$ of the sample stated they would continue using the new platforms once they went back to teaching in the classroom, and $84 \%(\mathrm{~N}=42)$ reported their institution to be very helpful in the process. Finally, $70 \%(\mathrm{~N}=35)$ of the overall participants specified that they covered all their Course Learning Objectives over the period.

A strong positive correlation was found between judgments regarding the ease of online teaching in the current crisis and the help offered by the teacher's institution, implying that the more the assistance offered, the easier the process was found by teachers $r=.58, \mathrm{p}<.01$.

In addition, a positive correlation was found between the use of video applications in place of traditonal face-to-face instruction (e.g. Zoom or Skype) and the teacher's comfort in using new resources $r=.28, p=.04$. For instance, teachers who used video applications displayed higher levels of comfort with regards to online teaching. A lack of equipment was positively correlated with: (1) the students' confusion when introduced to new material $\mathrm{r}=.40, \mathrm{p}=.01 \mathrm{and}$ (2) a reduction in working hours and or/pay for teachers $\mathrm{r}=.38, \mathrm{p}=.01$. In addition, student confusion was also positively correlated to the reduction of hours and/or pay of teachers, $r=.34, p=.04$. Platforms for posting work such as Google Classroom, Canvas and Blackboard were positively associated with technical complications $\mathrm{r}=.40, \mathrm{p}=.01$. (Table 3 ).

TABLE 3.

PEARSON'S CORRELATION MATRIX AMONG VARIABLES (N=50)

\begin{tabular}{|c|c|c|c|c|c|c|c|c|c|}
\hline & $\begin{array}{l}\text { Thoughts } \\
\text { on OT }\end{array}$ & $\begin{array}{l}\text { Institution } \\
\text { Help }\end{array}$ & $\begin{array}{l}\text { Video } \\
\text { Apps } \\
\end{array}$ & $\begin{array}{l}\text { Teachers } \\
\text { Comfort }\end{array}$ & $\begin{array}{l}\text { Unavailable } \\
\text { equipment }\end{array}$ & $\begin{array}{l}\text { Students } \\
\text { confusion }\end{array}$ & $\begin{array}{l}\text { Reduction } \\
\text { in hours }\end{array}$ & $\begin{array}{l}\text { Technical } \\
\text { complications }\end{array}$ & Platforms \\
\hline $\begin{array}{l}\text { Thoughts on } \\
\text { OT }\end{array}$ & -- & & & & & & & & \\
\hline $\begin{array}{l}\text { Institutional } \\
\text { Help }\end{array}$ & $.581 * *$ & -- & & & & & & & \\
\hline Video Apps & .113 & .117 & -- & & & & & & \\
\hline $\begin{array}{l}\text { Teacher } \\
\text { Comfort }\end{array}$ & .275 & .272 & $.285^{*}$ & -- & & & & & \\
\hline $\begin{array}{l}\text { Lack of } \\
\text { equipment }\end{array}$ & .178 & .145 & .102 & -.069 & -- & & & & \\
\hline $\begin{array}{l}\text { Students' } \\
\text { confusion }\end{array}$ & -.010 & .021 & .261 & -.108 & $.389 * *$ & -- & & & \\
\hline $\begin{array}{l}\text { Reduction in } \\
\text { hours/pay }\end{array}$ & .077 & -.045 & .202 & -.079 & $.372 * *$ & $.342 *$ & -- & & \\
\hline Technical & .211 & .162 & .060 & .081 & .116 & .066 & .123 & -- & \\
\hline Complications & & & & & & & & & \\
\hline Platforms & -.010 & .154 & -.272 & .047 & -.090 & -.071 & -.227 & $.393^{* *}$ & \\
\hline
\end{tabular}

A lack of training for teachers from the intuition was significantly associated the perception that too much preparation time was required from educators $\mathrm{F}(1 ; 48)=7.1, \mathrm{p}=.01$, with a positive correlation between these two variables, $\mathrm{r}=.35$.

TABLE 4.

REGRESSION ANALYSIS SUMMARY FOR A LACK OF TRAINING PREDICTING PREPARATION REQUIRED FROM EDUCATORS

\begin{tabular}{lrrrrr} 
Variable & B & SEB & $\beta$ & $\mathrm{t}$ & $\mathrm{p}$ \\
\hline (Constant) & .343 & .080 & & 4.27 & .000 \\
Lack of training for teachers and/or institutional support.390 & .147 & .359 & 2.65 & .010 \\
\hline
\end{tabular}

And finally, students missing online sessions or not completing the required work was associated with a lack of help from the teacher's institution, $\mathrm{F}(1 ; 48)=4.7, \mathrm{p}=.03$. (Table 5). 
TABLE 5.

REGRESSION ANALYSIS SUMMARY FOR INSTITUTIONAL HELP PREDICTING THE STUDENTS' ONLINE ATTENDANCE

\begin{tabular}{|c|c|c|c|c|}
\hline Variable & SEB & $\beta$ & $\mathrm{t}$ & $\mathrm{p}$ \\
\hline (Constant) & .132 & & 2.99 & .004 \\
\hline How is your institution helping you in online teaching?.189 & .088 & .298 & 2.16 & .036 \\
\hline
\end{tabular}

\section{DISCUSSION}

This research examines how the Covid-19 pandemic is posing challenges in the field of higher education and the views of teachers with regards to online teaching. When comparing online vs. the classroom learning environment, online learning was shown to be effective, eliminating barriers while providing increased convenience, flexibility and feedback (Ni, 2013). Interaction in an online environment promotes student-centred learning and encourages wider participation (Karayan \& Crowe, 1997; Smith \& Hardaker, 2000). However, its advantages may not be realised if a connection between the instructor and student is lacking in terms of lack of student interest in the material itself or the delivery methodologies of the instructor. Literature revealed that it is easier for participants to ignore the instructor in an online context $(\mathrm{Ni}, 2013)$. This would support one of the findings in this study when teachers mostly complained about students missing online sessions, or not completing the required work. In a face-to-face setting, the instructor can more easily control and interact with their students, reducing attendance and work completion issues. Another study reported dropout rates to be as high as $80 \%$ in online classes (Carr, 2000), which may be attributed to the mode of study itself as holding the attention of students during online learning is viewed as being challenging. The latter could explain teachers' concerns about the increased number of students missing their online sessions as this may lead to more severe consequences, such as drop out. As mentioned above, Lebanon is currently facing its worse financial and banking crisis since the Civil War which broke out in 1975 (Gardner, 2020). As per the Ministry of Education, 39,189 students switched from private to public schools during the current academic year (Babin, 2020). A large number of private schools are also facing delayed payments from parents, and some parents' committees are refusing to pay tuition fees. These factors are pushing many students to drop out and enter employment early to help provide for their respective families.

Participants in this study also complained that they encountered technical complications during online teaching such as incorrect or unknown passwords and platforms not working as expected. A paper by Wazzan (2020) revealed that educators and students struggled with connection problems despite the government's efforts to address the issue. In addition, 46\% ( $\mathrm{N}=23)$ of the sample stated that too much preparation time was required from teachers, which is in accordance with literature affirming that the time needed for preparation is generally longer than expected in online teaching (Wazzan, 2020). With regards to the completion of Course Learning Objectives, 70\% (N=35) reported themselves to be confident that they had covered the material. This finding is not in complete agreement with Wazzan's interviewees, who appeared to find difficulties in prioritizing and deciding how much of the curriculum could realistically be completed (2020).

With regards to institutional help and the support offered to teachers, this study revealed a lack of help was significantly associated with students missing online classes and completing the required work. In addition, a lack of training for teachers from the intuition was significantly associated with educators facing too much preparation time. In the case of Lebanon, the transition to online teaching was sudden and most institutions were unprepared. Literature recommends staff development strategies that focus on educating staff on how to become competent online teachers (Wilson \& Stacey, 2004). These strategies must not include only workshops, short courses and website support, but must also teach educators instructional design skills in order to integrate face-to-face interaction into the online environment.

Schools can deliver staff development support online in order to develop skills and knowledge around online teaching. Wilson and Stacey recommend staff development content and an approach spread over four levels. Level 1 includes "show and tell" activities with operational trainings, seminars on activities within the institution and guest speakers. Level 2 delves deeper into learning management system skills, discussion boards, role-play and debates to increase interactivity with students. Level 3 focuses on more complex technical knowledge and forms of online interactivity (e.g. case studies).

Finally, at level 4, educators are encouraged to engage in staff development programs where they become role models for others and act as resource for other staff. It is implied that not all educators embrace change at the same pace or in the same way. Thus, there is a need to encourage the utilization of development strategies that facilitate the transition process for all subjects, including both teachers and students.

\section{LIMITATIONS}

In interpreting the study's findings, it is important to note its significant limitation. The cross-sectional nature of the data prevented causal inferences, as a result no conclusions on causal relationships could be drawn between the variables (Fernie et al., 2018). Additionally, due to the Covid-19 pandemic, participants were recruited via email, thereby increasing the chances of sampling bias. This may have led to the misinterpretation of their responses as well as 
response bias. Future studies could use a more representative sample and a data collection method that would minimize sampling bias in order to enhance the general applicability of the results. It is further suggested to actively and randomly distribute the questionnaire to a larger number of interviewees across different locations in Lebanon.

Finally, given the unique nature of the economic crisis, limited literature was available with regards to how challenges of this nature might have a specific impact on teachers. Adopting a mixed approach with the introduction of a quantitative component may have allowed for a better understanding of the variables and how they affected participants.

\section{CONCLUSION}

Technology has provided increased opportunities for educators and learners to interact in both online and face-to-face settings. Both methods of teaching have their advantages and disadvantages. In this study, teachers were generally satisfied with their online teaching experience and they mainly complained about students missing lectures, technical complications, and a lack of institutional help and training. Most of the results were congruent with the literature and some suggestions where listed to enhance the overall experience around online learning. It should be mandatory for institutions to provide staff development programs. Most schools, including within Lebanon, are transitioning to virtual learning due to the Covid-19 pandemic, and measures could be implemented to better facilitate this transition.

\section{APPENDiX. TEACHER's QUESTIONNAIRE}

1. Your role is:
a. Administrator with teaching duties
b. Instructor/Lecturer/Teacher
c. Other:

2. How old are you?
a. Under 30
b. 30 to 40
c. 40 to 50
d. Above 50

3. What course do you teach?

4. $\overline{\text { How long have you been teaching online? }}$
a. Less than a week
b. 2 weeks
c. 3-10 weeks
d. I am not teaching online classes

5 . How many hours do you teach per week?
a. 2 to 4 hours
b. 4 to 6 hours
c. More than 6 hours

6. What do you think of online teaching following the crisis?
a. More difficult that I thought it would be
b. As expected
c. Very easy and simple

7. Which of the below statements apply to online teaching? (select any that apply)
a. Technical complications (lost or unknown passwords, platforms not working as expected...)
b. Concerns about academic transparency and integrity
c. Lack of training for teachers and/or institutional support
d. Students missing online sessions, or not completing the required work
e. Too much preparation required on the part of the teacher
f. Difficulty experienced by the teacher in managing teaching duties and other personal obligations
g. A lack of equipment (hardware, Wi-Fi...)
h. A reduction in working hours and/or pay for teachers
i. Student confusion when introduced to new material
j. No major issues
k. Other issues. Please write below

8. Which of the below have you continued using after the pandemic?
a. Video applications for face-to-face instruction such as Zoom, Skype or Teams
b. Platforms for posting work such as Google Classroom, Canvas, Blackboard or Class Dojo
c. Publisher platforms for course-related activities such as Pearson's MyLab or MyEnglishLab 
d. Non-publisher platforms for course-related activities such as Duolingo, Raz-Kids or Kahoot

e. Digitised books or ebooks

f. Texting applications as a mean of communication with students via Apps such as WhatsApp

g. Open Educational Resources (OER)

h. Educational websites such as YouTube or TedTalks

i. Assessment software with security measures

j. None of the above

9. Which of the below were available in your institution before the pandemic?

a. Platforms for posting work such as Google Classroom, Canvas, Blackboard or Class Dojo

b. Publisher platform for course-related activities such as Pearson's MyLab or MyEnglishLab

c. Non-publisher platform for course-related activities such as Duolingo, Raz-Kids or Kahoot

d. Digitised books or ebooks

e. Open Educational Resources (OER)

f. Assessment software with security measures

g. None of the above

10. How do you feel about using these new resources? Select a number from 1 to 5 , where $1=$ very uncomfortable, and $5=$ very comfortable
$3 \quad 4$
$4 \quad 5$

12

11. Do you think that you will continue using these resources once you go back to teaching in physical classrooms?
a. Yes
b. Maybe
c. No

12. How is your institution helping you regarding online teaching?

a. They have been helpful for most part

b. They have not been helpful for most part

c. I am not aware of any available help from the institution

d. I do not need the institution's help at this time

13. Did you cover the CLOs (Course Learning Objectives)?
a. All
b. Half
c. Quarter
d. Other:

\section{REFERENCES}

[1] Abu Habib, L. (2020). 2020 Outlook: Lebanon between the economic crisis and the aspirations of the October uprising. American University of Beirut Outlook. https://www.aub.edu.lb/ifi/news/Pages/20200217-lebanon-outlook-2020.aspx (accessed 28/05/2020).

[2] Allen, I., \& Seaman, J. (2010). Class differences: Online education in the United States. Newburyport, MA: Sloan.

[3] Ally, M. (2011). Foundations of educational theory for online learning. In T. Anderson \& F. Elloumi (eds.), Theory and practice of online learning (2rd edn.). Athabasca, Alberta, Canada: Athabasca University Press 3-32.

[4] Babin, J. (2020). The Economic Crisis has pushed 40,000 Students to Join Public Schools. Le Commerce Du Levanl. https://www.lecommercedulevant.com/article/29627-the-economic-crisis-has-pushed-40000-students-to-join-public-schools (accessed 28/05/2020).

[5] Bain, A., \& Ross, K. G. (2000). School reengineering and SAT-I performance: A case study. International Journal of Educational Reform, 9(2), 148-154.

[6] Carr, S. (2000). As distance education comes of age, the challenge is keeping the students. Chronicle of higher education, 46(23). https://www.chronicle.com/article/As-Distance-Education-Comes-of/14334 (accessed 28/05/2020).

[7] Fernie, B. A., Kopar, U. Y., Fisher, P. L., \& Spada, M. M., (2018). Further development and testing of the metacognitive model of procrastination: self-reported academic performance. Journal of Affective Disorders, 240, 1-5.

[8] Flowers, L. O., White, E. N., Raynor, J. E., \& Bhattacharya, S. (2012). African American Students' Participation in Online Distance Education in STEM Disciplines: Implications for HBCUs. SAGE Open. https://doi.org/10.1177/2158244012443544.

[9] Gardner, D. (2020). Lebanon's economic crisis requires an urgent decision on IMF aid. The Financial Times. https://www.ft.com/content/60c1896e-57d9-11ea-a528-dd0f971febbc (accessed 28/05/2020).

[10] Greenberg, G. (1998). Distance education technologies: Best practices for K-12 settings. IEEE Technology and Society Magazine, 17, 36-40.

[11] Karayan, S., \& Crowe, J. (1997). Student perspectives of electronic discussion groups. THE Journal: Technological Horizons in Education, 24(9), 69-71

[12] Nakhoul, S., \& Perry, T. (2019). Reeling from protests, what's next for Lebanon. Reuters. Web Transcription Tool. https://www.reuters.com/article/us-lebanon-protests-scenarios/reeling-from-protests-whats-next-for-lebanon-idUSKBN1X3272 (accessed 28/05/2020).

[13] Ni, A. Y. (2013). Comparing the effectiveness of classroom and online learning: Teaching research methods. Journal of Public Affairs Education, 19(2), 199-215. 
[14] Paechter, M., \& Maier, B. (2010). Online or face-to-face? Students' experiences and preferences in e-learning. The Internet and Higher Education, 13(4), 292-297.

[15] Project Tomorrow. (2006). Our voices, our future: Student and teacher views on science, technology \& education. Irvine, CA: Project Tomorrow.

[16] Smith, D., \& Hardaker, G. (2000). e-Learning innovation through the implementation of an Internet supported learning environment. Educational Technology and Society, (3), 1-16.

[17] Swicord, B., Chancey, J. M., \& Bruce-Davis, M. N. (2013). "Just What I Need" Gifted Students' Perceptions of One Online Learning System. SAGE Open, 3(2), 1-14.

[18] Wazzan, M. (2020). Learning Remotely as the Only Resort: How is Lebanon Doing?. Al Fanar Media. Web Transcription Tool. https://www.al-fanarmedia.org/2020/04/learning-remotely-as-the-only-resort-how-is-lebanon-doing (accessed 28/05/2020).

[19] Wilson, G., \& Stacey, E. (2004). Online interaction impacts on learning: Teaching the teachers to teach online. Australasian Journal of Educational Technology, 20(1), 33-48.

Maha Mouchantaf is an Assistant Professor at Notre Dame University (NDU), Louaize, Lebanon, and the former Chairperson of the Department of English, Translation, and Education. She holds a Ph.D. in Educational Management from Université de Corse France, an M.A. in Educational Management from the Lebanese American University, Lebanon, and a B.A. in Communication Arts, Journalism and Radio/T.V. Production from the same university.

Her research has mainly focused on exploring gender differences, cultural diversity, and leadership styles in administration. She has rich experience in school management and her research interests continue to center on issues related to shaping better le aders as well as bridging the gaps in the Lebanese education system, and service learning. She participated in the evaluation of the project "Relief and Reconciliation for Syria" carried out by FLPS/GIR and LERC from NDU.

She has conducted several trainings and workshops on leadership and management and prevention of violent extremism with the British Council. She has published on female leadership in Lebanon and on issues pertaining to gender differences in school administration and service learning. 